\title{
Intellectual offshoring as tool of regional innovative system development
}

\author{
Elena Tkachenko \\ Dept. Economy and Management of Enterprises and \\ Industrial Complexes \\ St. Petersburg State University of Economics, St. \\ Petersburg, Russia \\ eletkachenko@ya.ru \\ Elena Rogova \\ St. Petersburg School of Economics and Management \\ National Research University \\ Higher School of Economics, St. Petersburg, Russia \\ erogova@hse.ru
}

\author{
Sergey Bodrunov \\ Institute for New Industrial Development \\ St. Petersburg, Russia \\ inir@inir.ru
}

\author{
Timur Shakirov \\ Dept. Economy and Management \\ of Enterprises and Industrial Complexes, \\ St. Petersburg State University of Economics, St. Petersburg, Russia, \\ timur.shakirov18@gmail.com
}

\begin{abstract}
The problem of knowledge management in the context of offshoring is generally related to the issues of intellectual property rights defense $[15,6,4]$. This study differs from these research issues by the analysis of so called intellectual offshores from the viewpoint of regional economies. Intellectual off-shores are considered as specific tools for increasing efficiency of knowledge and technology transfer. One of the innovative methods for offshoring is the spatial crowd-investing. It is used for attracting funding to intellectual offshores development. Crowd-investing becomes increasingly popular in the conditions of limitedness of sources for investments. Intellectual off-shores are usually perceived as large infrastructure projects. Usually, when pooling funds for such projects, the minimal investment stock is fixed; this helps to limit the number of potential stakeholders and makes relationships between them more transparent and simple. It is worth noting also that such projects, in fact, erase the difference between institutional and private investors in their access to regional knowledge stock. It means that both institutions, as funds and private investors, can participate in large infrastructure projects funding and knowledge creating. The pooling of private stakeholders diminishes the regional budgets' burden and helps to solve the problem of effective knowledge and technology transfer within regional economies.
\end{abstract}

Key words - Intellectual off-shores; innovative development; regional economy.

\section{INTRODUCTION}

The problem of the development and operation of information offshores has been actively discussed in economic literature over the last 20 years. Strasser and Westner [14] noted that, as a rule, the offshoring of information systems means the transfer of services for the creation and maintenance of information systems in third countries in relation to its users. Countries, specialising in similar service provision on a global scale, have emerged over recent decades. Russia plays a very important role in this process. In 2016, the export of services and products produced by Russian IT companies amounted to USD 7.5 billion. The importance of Russian companies for international IT outsourcing is noted in the Gartner review [3] and their role has increased since then. However, the key region of the Russian Federation with the highest concentration of IT industry is St. Petersburg. According to the estimation of Russoft, as much as 50\% of the total IT industry exports from Russia belong to the companies located in St. Petersburg. The authors have raised an issue of IT sector impact on the development of regional economy in this research. The authors have analysed the correspondence of information infrastructure development to the goals and objectives of knowledge economy development, identified the problems of economic development in St. Petersburg in accordance with the formation of knowledge economy, and substantiated the feasibility of intellectual offshore creation in the territory of the region.

\section{PROBLEM OF TERMINOLOGY CHOICE}

The problem of terminology arises from the taxonomy of the term "IT offshore". Traditionally, in economic literature $[10,5,11]$, an offshore means a territory with a special tax regime. At the same time, an offshore involves the usage of various economic opportunities and resources outside the territory of the company's resident country. The terms "outsourcing" and "offshore" merged with the production of software and IT services at a certain stage. The terms "IT offshore" and "ISO offshore" mean production outsourcing of 
IT products and services in different sources [8, 2, 16, 14]. At the same time, such authors as Yalaho and Nahar [17], and Prifling, Gregory, and Beck [13] use the terms "IT offshoring" and "IT outsourcing" simultaneously. To define the authors" position clearly, they use the term intellectual offshore to designate a territory with a special economic regime for companies in the IT sector and high-tech R\&D companies.

\section{ANALYSIS OF THE CURRENT ECONOMIC REGIME OF ST. PETERSBURG IN THE FIELD OF INFORMATION TECHNOLOGIES AND TECHNOLOGY TRANSFER.}

As it has been already mentioned above, St. Petersburg is one of the developing centres of the IT industry. The number of employees in IT cluster companies exceeds twenty thousand people, not including small companies who fall outside of official statistics monitoring. At the same time, the contribution of this industry to the development of the knowledge economy is not high. Most IT companies do not generate multiplicative effects for urban economy. In order to understand the crux of the problem, it is enough to compare soft data of the annual export ratio of IT products and services of St. Petersburg companies (USD 3.5 billion) with Federal Customs Service export data of IT products from St. Petersburg (USD 345 million). The reason for this lies in the specifics of the product itself determining the possibility of intangible transboundary movement. As a rule, commercial transactions are carried out through foreign representative offices, being residents of financial offshores. As a result, there is no real improvement in the system of information flows generation and transmission on the territory of St. Petersburg, or these processes are carried out extremely slowly.

The city authorities, facing the problem of the low involvement level of the IT sector in the formation of St. Petersburg GRP, created a special economic zone of technicalinnovative type in the territory of the city 10 years ago. Originally, the project was designed for 20 years; resident enterprises receive full exemption from land tax, estate tax, and transport tax payment, and are also exempted from customs duties and VAT on imported technological equipment. Preferential prices for redeemed and leased land plots are set for these enterprises. Residents pay profit tax at a reduced rate of $13.5 \%$ (against $20 \%$ in the territory of the Russian Federation). In addition, benefits for retirement pension contributions and the Federal Compulsory Medical Insurance Fund are established.

Despite significant benefits, the expected explosive growth of knowledge economy in St. Petersburg did not happen. Proven models minimising taxation by means of the use of foreign financial offshore schemes proved to be more attractive than exemption schemes. Even enterprises, which are residents of SEZ, are focused on investing outside the territory of the Russian Federation, not on free financial resources reinvesting in the development of intellectual assets in St. Petersburg.

\section{PROBLEMS OF REGULATORY SUPPORT OF INTELLECTUAL PROPERTY IN THE RUSSIAN FEDERATION.}

As a measure to stimulate the development of the knowledge economy, the authors propose the creation of a special economic regime in St. Petersburg - the St. Petersburg Intellectual Offshore.

The task to create a mechanism for the implementation of this project is game-changing, as there are currently no offshore companies specialising in the proclaiming of a regime of free information and innovation space in the world.

Firstly, it is necessary to introduce amendments to the basic law "About Special Economic Zones in the Russian Federation" dated July 22, 2005, No. 116. It is necessary to introduce a new type of SEZ - information and technological offshore. It is necessary to abolish the size restriction of the territory, since the offshore company is created within the administrative boundaries of St. Petersburg. It is limited to technology parks and large companies, dealing with software, research, and development in the field of high technologies, having practically no large-scale production, and operating exclusively in office premises, research laboratories and small experimental production sites.

This project does not imply any officially defined terms of realisation. The offshore regime is introduced for an indefinite period; full tax exemption of companies is planned for 10 years from the moment of registration within the offshore area.

The implementation of a project as complex as an information offshore requires a particular management system from the government. An offshore is an innovative project, assuming the combination of phases of scientific and manufacturing cycles, and is orientated towards the achievement of specific results (creation of the information infrastructure and $R \& D$ development) during the process of its practical realisation. The peculiarity of intellectual offshore predetermines the particular importance of quality of its development, and estimation of the economic viability of its realisation. For these purposes, it is important to have a clear vision of context of the creation process of the offshore, and to follow a schedule of work cycle of project implementation and offshore creation (see Table 1).

Also, it is necessary to mention that the active use of the concept of public-private partnership is an important element of the offshore creation mechanism. First of all, it is proposed to use the scheme of public-private partnership while working on strategically important directions of the development, such as information security and technology for the militaryindustrial sector. Indeed, the main challenge of a high level of informatisation (including government agencies) is the threat of cybercrime. This problem cannot be solved by simple strengthening of state control over the Internet network and legislation tightening. On the contrary, the excessive control and the policy management implementation in the leadership of the largest IT companies, to some extent close to the state, reduces the attractiveness of the market for investors. The authors believe that it is possible to raise the level of information security by increasing the competence of the 
personnel who are in the service of the relevant departments and institutions, and also through the cooperation of these structures with private companies. This principle is also relevant for the military-industrial sector. The authors believe that it is more efficient to transfer a part of the projects to be outsourced to third parties, improving the quality of the final product.

TABLE I. ENGINEERING WORK CYCLE AND CREATION OF INTELLECTUAL OFFSHORE

\begin{tabular}{|c|c|c|c|c|c|c|c|}
\hline \multicolumn{4}{|c|}{ Pre-investment phase } & \multicolumn{2}{|c|}{ Investment phase } & \multicolumn{2}{|c|}{ Operating phase } \\
\hline $\begin{array}{c}\text { Details } \\
\text { of the } \\
\text { project } \\
\text { idea }\end{array}$ & $\begin{array}{c}\text { Stage of } \\
\text { the } \\
\text { project } \\
\text { objective }\end{array}$ & $\begin{array}{c}\text { Stage of } \\
\text { the } \\
\text { forming } \\
\text { of the } \\
\text { project } \\
\text { outline }\end{array}$ & $\begin{array}{c}\text { Stage of } \\
\text { estimation } \\
\text { and } \\
\text { decision } \\
\text { making }\end{array}$ & $\begin{array}{c}\text { Stage of } \\
\text { execution } \\
\text { of the } \\
\text { contract } \\
\text { with } \\
\text { prospectiv } \\
\text { e } \\
\text { investors }\end{array}$ & $\begin{array}{l}\text { Stage of } \\
\text { engineerin } \\
\mathrm{g} \text { of } \\
\text { facilities } \\
\text { and } \\
\text { provision } \\
\text { of the sites }\end{array}$ & $\begin{array}{r}\text { Start } \\
\text { stage }\end{array}$ & $\begin{array}{c}\text { Operatin } \\
\mathrm{g} \\
\text { stage }\end{array}$ \\
\hline
\end{tabular}

Development perfection, and specification of the offshore project

Also, it is necessary to mention that the active use of the concept of public-private partnership is an important element of the offshore creation mechanism. First of all, it is proposed to use the scheme of public-private partnership while working on strategically important directions of the development, such as information security and technology for the militaryindustrial sector. Indeed, the main challenge of a high level of informatisation (including government agencies) is the threat of cybercrime. This problem cannot be solved by simple strengthening of state control over the Internet network and legislation tightening. On the contrary, the excessive control and the policy management implementation in the leadership of the largest IT companies, to some extent close to the state, reduces the attractiveness of the market for investors. The authors believe that it is possible to raise the level of information security by increasing the competence of the personnel who are in the service of the relevant departments and institutions, and also through the cooperation of these structures with private companies. This principle is also relevant for the military-industrial sector. The authors believe that it is more efficient to transfer a part of the projects to be outsourced to third parties, improving the quality of the final product.

It is necessary to develop criteria for selecting companies that are eligible for offshore registration. One should anticipate the situation when there will be attempts at unfair registration in offshores by providing deliberately false data on the type of activity that provides for a regime of preferential taxation, and as a practical matter in work in other fields. This is a serious problem requiring the collaborative work of specialists of both economic and legal profiles, as well as the creation of criteria assessing the conformity of the type of company's activity to offshore conditions. Apparently, the examination of compliance will be required not only during the process of registration, but also regularly in the process of activity, in order to avoid abusive practices. To avoid such situations, regular audit is probably needed. By establishing a certain indicator, it is possible to secure the offshore from abusive practices. For example, at least $90 \%$ of the company's profits should accrue from activities that are related to information technology.

The key principle according to which the program of offshore creation will be realised in St. Petersburg is a principle of publicity and transparency. Classically, in offshore jurisdictions, information about financial operations, management, and ultimate beneficiary of business is hard to obtain or indeed is completely inaccessible. In this case, the term "offshore" will have nothing in common with those in a similar area. First of all, it is important in order to avoid registration of companies with doubtful reputations. Also, it is important to monitor the company's profits and to generate reports about the correspondence of activity type with the offshore's requirements.

Let us propose the creation of a specialised website dedicated to this offshore, where news will be published, and a list of all resident companies will be available, as well as the status of work on projects and advanced developments within the framework of the open innovation ideology described above.

\section{RESEARCH METHODOLOGY}

The research is based on the methods of logical and statistical analysis and modelling. The data on the regional statistics have been provided by the Federal State Statistics Service of the Russian Federation, and information on regions in the context of the IDI index has been used. One of the tasks of the authors' research was to reveal the influence of the development of information factors on the pace of knowledge economy formation. One of the key factors in the process of knowledge economy formation in modern conditions is foreign direct investments as a basis for the broad transfer of high technologies. Ratings of investment attractiveness also influence the level of attracting investments.

To identify the dependence of regional investment attractiveness on the state of information infrastructure, a regression model has been built using Microsoft Excel software.

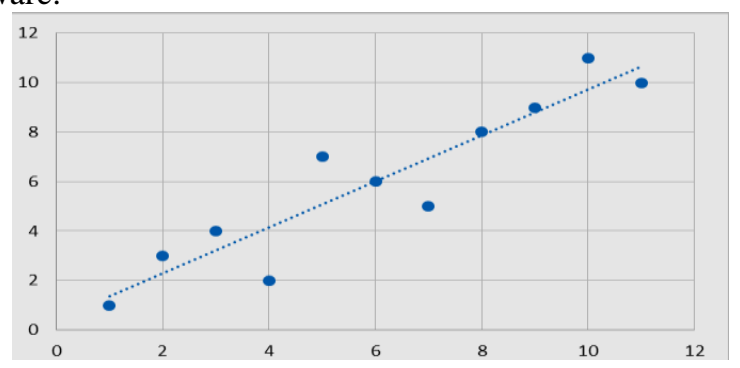

Fig. 1. Dependence of investment attractiveness on the level of information infrastructure development 
TABLE II. REGRESSION STATISTICS

\begin{tabular}{|l|r|}
\hline Multiple R & 0.927 \\
\hline R-squared & 0.859 \\
\hline Normalized R-square & 0.844 \\
\hline standard error & 1.308 \\
\hline Observations & 11 \\
\hline
\end{tabular}

$\mathrm{R}$-squared is 0.85 in this model, demonstrating proof of interconnection. In accordance with regression analysis results, the variation of regional area in investment potential rating is stipulated by IDI $^{1}$ index variation by $85 \%$.

TABLE III.

VARIANCE ANALYSIS.

\begin{tabular}{|l|l|l|l|l|l|}
\hline & df & SS & MS & F & $\begin{array}{l}\text { Significance } \\
\text { of F }\end{array}$ \\
\hline Regression & 1 & 94.58182 & 94.58182 & 55.20991 & 0.000039 \\
\hline Rest & 9 & 15.41818 & 1.713131 & & \\
\hline Total & 10 & 110 & & & \\
\hline
\end{tabular}

TABLE IV. COMPARISON OF IDI1 AND REGIONAL COMPETITIVENESS INDEX

\begin{tabular}{|c|c|c|c|c|}
\hline Value & IDI ranking & $\begin{array}{l}\text { Subject of the Northwestern } \\
\text { Federal District }\end{array}$ & $\begin{array}{l}\text { Index of } \\
\text { competitiveness of the region }\end{array}$ & $\begin{array}{l}\text { The place in } \\
\text { ranking }\end{array}$ \\
\hline 8.25 & 1 & St. Petersburg & 3.95 & 1 \\
\hline 7.08 & 2 & Kaliningrad region & 2.18 & 3 \\
\hline 6.78 & 3 & Murmansk region & 2.06 & 4 \\
\hline 6.62 & 4 & Leningrad region & 2.79 & 2 \\
\hline 6.4 & 5 & Vologda region & 1.26 & 7 \\
\hline 6.35 & 6 & Komi Republic & 1.65 & 6 \\
\hline 6.34 & 7 & Arkhangelsk region & 1.73 & 5 \\
\hline 6.23 & 8 & Republic of Karelia & 1.21 & 8 \\
\hline 6.17 & 9 & Novgorod region & 1.09 & 9 \\
\hline 5.98 & 10 & Pskov region & 0.34 & 11 \\
\hline 3.94 & 11 & Nenets Autonomous District & 0.7 & 10 \\
\hline
\end{tabular}

There is a high impact of information infrastructure on the innovation of regional economy, similar to the previous case. Determination coefficient (R-squared) is 0.85, and Fisher`s ratio test equals $5.12(\mathrm{~F}$-test $=55.2)$. The variation of regional competitiveness index is stipulated by the variation of IDI $^{1}$ index by $85 \%$.

\section{FINANCING MECHANISM OF THE INTELLECTUAL OFFSHORE}

Using a specialised site as a platform, it is possible to use an innovative mechanism for invitation of resources for the needs of the offshore project, especially for the Russian Federation in conditions of an inhibition of access to international capital. This refers to the model of crowdfunding, namely, crowdfunding in the field of territory marketing. The sequence of stages of attracting financial resources using this tool is shown in Fig. 2.

Generally, when talking about large infrastructure projects, a minimum amount of investments is registered in order to
As Table 3 shows, the F-test equals 55.2. According to the table, with values of the Fisher test one calculates that this Ftest equals 5.12. it is obvious that the calculated F-test is larger than the table value, so it is proof of the statistical significance of the model. Let us construct the final regression equation:

$$
S=0.43+0.92 x
$$

To exclude a possible error and fix obtained results, as well as proving the relevance of modified IDI $^{1}$ instead of investment attractiveness indicator, let us fix the indicator "competitiveness index" compiled by the experts of the Leontief Centre 1. Comparison of the $\mathrm{IDI}^{1}$ and regional competitiveness index is shown in Table 4. limit the number of potential stakeholders and, as a result, to simplify the process of payments to them. It is also necessary to admit that this innovative mechanism removes the border between private and institutional investors. As a result, both individuals and various commercial structures and funds can put up a large infrastructure project for discussion and finance.

The main advantage of this model for the government is that direct backing from individuals allows them to avoid appeals to institutional investors, and one benefit for individuals is the savings on commission.

Thereby, the financing scheme for the intellectual offshore development project will include the following sources:

Part of the investment in the infrastructure of the city will be conducted within the existing programs of informatisation at the federal and regional levels;

Territorial crowdfunding. In the case of a high level of informatisation and a close relationship with authorities, let us consider such instruments for financing state projects as quite practicable; 
other extra-budgetary sources, such as private investment, as well as the development of the format of public-private partnership.

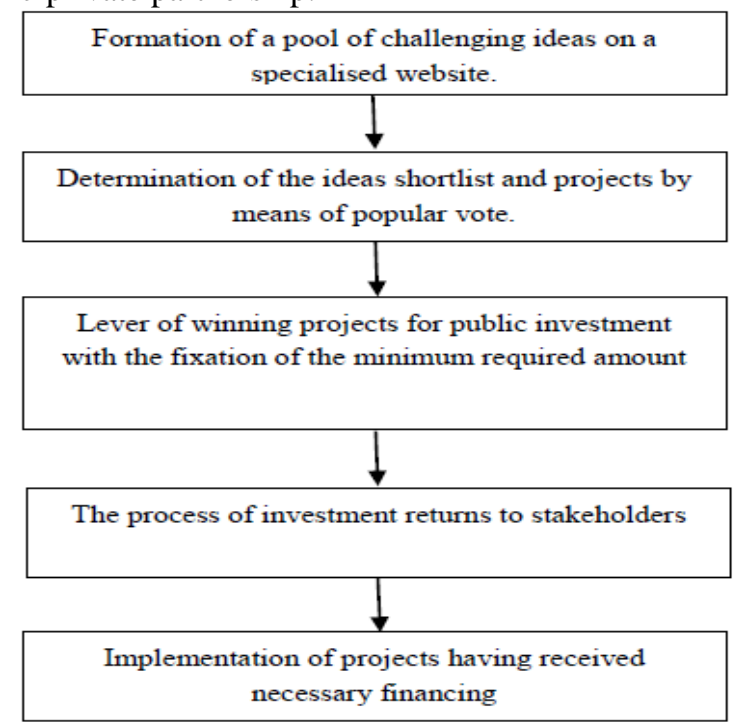

Fig 2. Sequence of stages in territorial crowdfunding

\section{RISKS OF INTELLECTUAL OFFSHORE PROJECT REALISATION}

During the process of program realisation, individual attention should be paid to public guaranties. First of all, it is necessary to secure local and international business from any changes to taxation conditions, to provide the offshore with full autonomy for the foreseeable future in order to invite long-term projects.

Also, personnel questions will arise with the increase in the number of companies and promising developments. It is obvious that the number of graduates of technical and ITspecialities, and specialists in engineering specialities, will not satisfy the demands of the market. Even today there is a serious deficit of highly qualified specialists. This means that it will be necessary to increase the number of graduates of profession-orientated specialities, including those backed using private capital. Let us also offer public funding for training students on profession-orientated specialities abroad, with the condition of compulsory post-graduation work for a certain period in the territory of Russia to compensate for their funding. As part of the program of creation of an intellectual offshore, let us also consider it necessary to develop a set of measures to create a centre for the attraction of highly skilled employees to the city.

Increasing the data transmission speed and users of the service will result in a significant increase in network traffic, which will increase the hardware requirements. Therefore, together with the development of broadband Internet, simultaneous construction of large data centres is necessary. This will enable the business to outsource processing power, as well as to significantly increase the level of national information security, as it will reduce the need for crossborder data transmission.
The authors believe that the most serious risks are:

- Organisational. A large number of participants and stakeholders in the offshore project implementation process will require professional management, and operational interaction of responsible state bodies. Guaranties at a high state level about a special attitude and high interest in the offshore project on the part of the state are also needed, in order to solve the possible issues and disputes as a matter of priority;

Financial. Threat of irrational use of funds, and financing in insufficient volumes. Implementation of the program will require additional investment along with already functioning strategies;

Political. The offshore project is sensitive to the interest of foreign companies. A complicated geopolitical situation could increase the risks for potential foreign residents, which would negatively affect the efficiency of the functioning and development of the project;

Staffing. Lack of skilled employees. The general trend for highly qualified personnel leaving the country. Difficulties in attracting specialists from abroad due to fluctuations in the national currency exchange rate, and general political and economic instability.

- Legal. The necessity of public guaranties on residents' protection from changes in the regulatory framework.

It should be mentioned that risk management should be one of the key components of the program implementation mechanism, since an underestimation of this tool can cause, among other things, significant resource losses.

The authors believe that the main synergetic effect of the development of the city's information infrastructure will be the development of new knowledge-intensive branches, as well as the transition of key economic branches to a whole new level of efficiency and competitiveness. Modern information products will be introduced into the industrial processes of industrial enterprises, and will become drivers for the development of the concept of the "smart city".

In terms of quantitative indicators, the difference between the inertial and innovative scenarios is shown in Fig. 3.

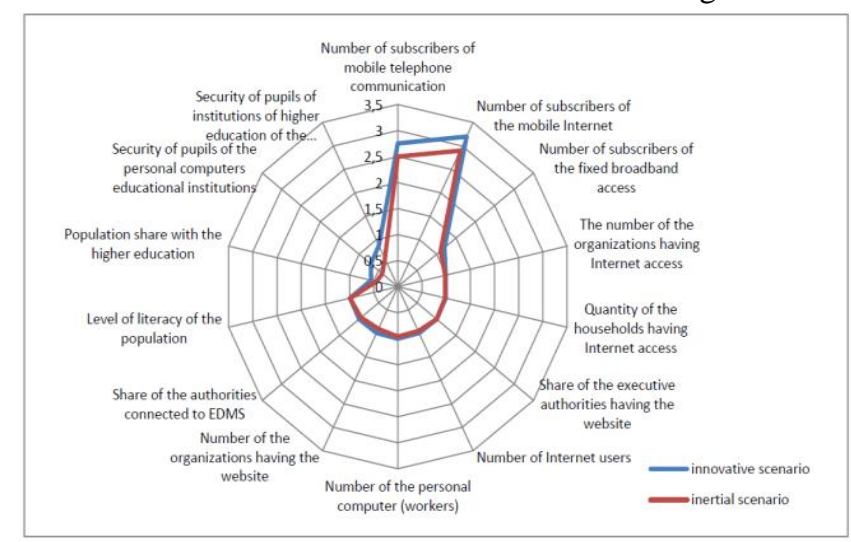

Fig. 3. Comparing of IDI indicators of inertia and innovative approaches. 


\section{CONCLUSION.}

The value of joint IDI $^{1}$ in the case of the realisation of this innovative scenario will amount to 12 . The key driver of growth will be the development of human capital asset. It should be mentioned that the relatively small delta of meaning of both scenarios is the result of the matching of a limited group of factors, reflecting only quantitative expression of development dynamics. However qualitative effects, which are expected to be a result of an intellectual offshore regime, are far more important. It should also be mentioned that along with indicators of economic effect, it is necessary to take into account the social effect indicators characterising the result of the offshore impact on the economy of the region.

\section{References}

[1] M. Amberg, M.Wiener "IT-Offshoring. Management internationaler ITOutsourcing-Projekte", Physica, Heidelberg, 2006.

[2] C.-P. Deng, J.-Y. Mao "Knowledge transfer to vendors in offshore information systems outsourcing", Journal of Global Information Management, Volume 20, Number 3, pp. 1-22, 2012.

[3] Gartner review 2010 [http://www.gartner.com/ newsroom/id/1500514]

[4] D. Ghelfi "The outsourcing offshore Conundrum: An Intellectual Property Perspective" WIPO Online: [http://www.wipo.int/sme/en/documents/outsourcing_fulltext.html]

[5] I. Grinberg, "The battle over taxing offshore accounts". UCLA Rev 60, pp. $304-383$

[6] P. Knapp "Why companies rushing to outsource their IT may be making mistake?" Online: [www.brainbox.com.au/]

[7] S.K. Mathew, Y. Chen, Y. "Achieving offshore software development success: An empirical analysis of risk mitigation through relational norms", The Journal of Strategic Information Systems, Volume 22, Number 4, pp. 298-314, 2013.
[8] A. Mathrani, D. Parsons, S. Mathrani "Knowledge management initiatives in offshore software development: Vendors' Perspectives". Journal UCS, Volume 18, Issue 19, pp. 2706-2730, 2012.

[9] Meng-chun Liu, Shin-Horng Chen "MNCs' offshore R\&D networks in host country's regional innovation system: The case of Taiwan-based firms in China Research Policy", Volume 41, Issue 6, pp. 11071120, July 2012.

[10] E S. W. Ng, R.J. Burke "Person-organization fit and the war for talent: does diversity management make a difference?" International Journal of Human Resource Management, Volume16(7), pp. 1195-1210, 2005.

[11] D. O’Donnell, G. Porter, D. McGuire, T.N. Garavan, M. Heffernan, P. Cleary "Creating intellectual capital: a Habermasian community of practice (CoP) introduction", Journal Eur. Ind. Train, Volume 27, pp. 80-87, 2003.

[12] S. Patil, Y.S. Patil, "A Review on Outsourcing with a Special Reference to Telecom Operations" Procedia Social and Behavioral Sciences, Volume 133, pp. 400-416, 15 May 2014.

[13] M. Prifling, R. Gregory, R. Beck "Changing psychological contracts and their effect on control modes in IT offshore outsourcing projects - A case from the financial services industry", Proceedings of the 42th Annual Hawaii International Conference on System Sciences (HICSS), Hawaii, 2009.

[14] A. Strasser, M. Westner, Knowledge Transfer in IS Offshoring: Processes, Roles, and Success Factors. In PACIS, 2015 Online [http://www.pacis-net.org/file/2015/2862.pdf ]

[15] H. Teran "Intellectual Property Protection and Offshore Software Development: An Analysis of the U.S. Software Industry", Minn. Intell. Prop. Rev. Volume 2, Issue 1, 2001, Online: [http://scholarship.law.umn.edu/cgi/viewcontent.cgi?article=1366\&conte $\mathrm{xt}=\mathrm{mj}$ lst $]$

[16] M. Wiener, B. Vogel, M. Amberg, M. "Information systems offshoring a literature review and analysis". Inf. Syst. 2010, Volume 27, pp. 455492.

[17] A. Yalaho, N. Nahar, "The ICT-supported unified process model of offshore outsourcing of software production: exploratory examination and validation”. Int. J. Innov. Technol. Manag, Volume 1, Issue 06, pp. 59-96, 2009. doi:10.1142/S0219877009001546 